This item was submitted to Loughborough's Research Repository by the author.

Items in Figshare are protected by copyright, with all rights reserved, unless otherwise indicated.

\title{
Green growth or ecological commodification: debating the green economy in the Global South
}

PLEASE CITE THE PUBLISHED VERSION

http://dx.doi.org/10.1111/geob.12049

\section{PUBLISHER}

Wiley / article @ The authors. Journal @ Swedish Society for Anthropology and Geography

\section{VERSION}

AM (Accepted Manuscript)

\section{PUBLISHER STATEMENT}

This work is made available according to the conditions of the Creative Commons Attribution-NonCommercialNoDerivatives 4.0 International (CC BY-NC-ND 4.0) licence. Full details of this licence are available at: https://creativecommons.org/licenses/by-nc-nd/4.0/

\section{LICENCE}

CC BY-NC-ND 4.0

\section{REPOSITORY RECORD}

Brown, Edward D., Jonathan M.P. Cloke, Danielle K. Gent, Paul H. Johnson, and Chloe J. Hill. 2019. "Green Growth or Ecological Commodification: Debating the Green Economy in the Global South". figshare. https://hdl.handle.net/2134/19335. 


\section{Green Growth or Ecological Commodification: Debating the Green Economy in the Global South}

Ed Brown (Loughborough University), Jonathan Cloke (Loughborough University), Danielle Gent (Loughborough University), and Paul H Johnson (Durham University) ${ }^{1}$ with Chloe Hill (Independent Consultant) ${ }^{2}$ 


\title{
Green Growth or Ecological Commodification: Debating the Green Economy in the Global South
}

\begin{abstract}
This paper examines recent institutional thinking on the green economy and the implications of official understandings and structuration of a green economy for the Global South. Assertions about the transformative potential of a green economy by many international actors conceals a complexity of problems, including the degree to which the green economy is still based on old fossil economies and technical fixes, and the processes through which the green economy ideation remains subject to Northern economic and technical dominance. The paper places the intellectual roots of the green economy within a broader historical context and suggests some ways the strategic economic and ideological interests of the Global North remain key drivers of green-economy thinking. The analysis is substantiated through two illustrative Latin American examples: the Mesoamerican Biological Corridor and green economy initiatives in Brazil. These suggest that, if the green economy is to address global challenges effectively, it must be conceptualised as more than a bolt-on to existing globalizing capitalism and encompass more critical understandings of the complex socio-economic processes through which poverty is produced and reproduced and through which the global environment is being transformed, a critique which also applies to mainstream discourses of sustainable development.
\end{abstract}




\section{Introduction}

The green economy has emerged as the latest big idea in international discussions on the construction of a global sustainable future (OECD, 2011; UNEP, 2011; World Bank, 2012). Whilst the notion has longer historical roots, the green economy concept has become increasingly prominent across a range of academic and institutional in recent years. An simple illustration of this can be found in the number of academic articles featuring 'green economy' in their titles from Google Scholar searches: these have grown from just 12 articles in 2004/5, to 164 in 2007/8, 430 in 2009/10 and 622 in 2012/13, with the numbers likely to grow further in 2014/15.

Our interest in the term evolved from increasing encounters with the concept within academic and institutional settings. For example, our involvement in the UK Low Carbon Energy for Development Network has led to a range of collaborative activities exploring the growth of low-carbon energy technologies across the Global South. We became aware of the influence of green-economy thinking during interactions with UK companies and policy-making communities within UK ministries and international agencies, both of whom frequently couched their activities within the context of the construction of a green economy. In the international development arena, the green economy also featured heavily in documentation produced in the run-up to the Rio+20 summit; ${ }^{3}$ to the extent that some suggested that it was replacing sustainable development as the dominant way of conceiving the global relationship between economy, society and environment (Unmüßig et al., 2012).

Such developments pose a number of key questions. From where has the green economy idea emerged? How does it relate to other ways of conceptualising environment and development relationships (how does it fit into the competing 
discourses of sustainable development and neoliberal perspectives that exert such a strong influence globally), and what are the implications of its presence within the international institutional arena, particularly for countries in the Global South?

In this paper we address these questions by exploring the institutional dynamics behind the contested intellectual hinterland of the green economy and by examining key actors and themes responsible for its evolution. Having established the intellectual foundations of the concept, we then examine its influence on current international development agendas and its policy implications for the Global South. One central theme identified is the tendency towards technocracy, seen, for example, in the propensity to view green economy pathways as amenable to techno-fixes (Crist, 2007), a position which overlooks the complex socio-economic processes that create poverty, ecological crises and marginalization. We also explore the interplays of power that have directed the development of green-economy ideation in practice. To illustrate this, we utilize two case studies: the Mesoamerican Biological Corridor (MBC) in Central America and green economy policies in Brazil, to examine green economy praxis in Latin America. The MBC provides an interesting example since it is presented as occupying high importance in the development of the green economy idea, having been embraced by the World Bank as a poster-child of market-focused sustainable development, whilst its latest manifestations in Southern Mexico are seen as providing an exemplar of the green economy in practice (Sarukhan and Icaza, 2012). Brazil is similarly symbolic, not just for the environmentally-aware social and economic policies initiated under recent administrations, nor even the pivotal place of Brazil's biodiversity, but because of Brazil's self-proclaimed global green-economy leadership. 


\section{Green Economy: Ideation}

As Carl Death suggests, the origins of the term green economy can be traced to the radical environmentalism of the 1960s and 1970s, where it was used to frame calls for “a radical revolutionary transformation of economic (and hence social and political) relationships to bring them in line with natural limits and ecological virtues” (Death, 2014:16). These radical connotations have gradually faded, however, particularly following the phrase's uptake by those involved in institutionalizing environmental concerns into mainstream economics through the development of environmental economics (see Jacobs 1991; Pearce et al. 1989). Ideas drawn from such works (for example, the role of economics in postulating solutions to market failures) were also evident in the Brundtland Report (Brundtland, 1987) and mainstream approaches to sustainable development that were consolidated following the first Rio Summit in 1992. Bill Adams argues that this mainstream endorsement has been characterised by a reformism which does not significantly challenge the "dominant capitalist industrializing model” but rather focuses on modifying its "methods and outcomes" (Adams, 2009:117) to address ecological and developmental crises. This approach has featured a somewhat schizophrenic mix of interventionist/managerialist approaches that attempt to regulate capitalism in pursuit of environmental and social objectives, and market-friendly/liberalizing impulses that seek to value and commodify environmental resources/services. Over time, the neoliberal-liberalizing, deregulating and privatizing components have become more dominant (see the wider literature on the relationship between mainstream sustainable development thinking and neoliberalism: Himley, 2008; Raco, 2005; While et al, 2010).

Interestingly, during the years following Rio, the term green economy did not feature prominently in dominant formulations of sustainable development and it 
seemed to have disappeared from common usage in international development circles until its recent rebirth. The re-emergence of the green economy idea stems from two particular bodies of work with slightly different emphases and antecedents. ${ }^{4}$ The first is the concept of green growth, whose ascendancy derives particularly from its promulgation by the World Bank and OECD. The former began seriously advocating the idea over a decade ago (World Bank, 2003) and has directed considerable resources into initiatives like the Green Growth Knowledge Platform, ${ }^{5}$ whilst the OECD's most influential intervention was the publication of Towards Green Growth in 2011. In the Bank's case, despite a focus on the crisis-inducing inefficiencies of the current economy and the economic potential of green opportunities, its advocacy of green growth could be conceived as a new component of its broader economic liberalization agenda. From this perspective, green growth is basically about “addressing market failures and 'getting the price right' by introducing environmental taxation, pricing environmental externalities and services... creating tradable property rights, and reducing inappropriate subsidies” (World Bank, 2012). The OECD’s perspective draws upon the Bank's work but focuses strongly on the production and employment of green technologies and how incorporating natural capital into economic measurement and management can boost employment, productivity, innovation and market creation.

Clearly then, much of the green growth agenda is driven by the desire of Northern economies to secure raw materials and find new sources of growth for the “over-accumulated capital that seeks new investment opportunities” in the continuing fallout from the global financial crisis (Brand, 2012). Whilst proffering many of the same market-based solutions, within the United Nations the green economy has been more directly conceptualized as part of the sustainable development agenda. Here, the 
major agency involved has been the United Nations Environment Programme (UNEP). Its perspective is most clearly expressed in the 2011 report Towards a Green Economy, which stressed the "gross misallocation” of global capital (caused by a lack of effective means of assigning market value to environmental externalities) that encouraged global capital to pour into unsustainable activities, particularly those associated with property, fossil fuels and financial market products, including derivatives. It argued that comparatively little had been invested in renewable energy, energy efficiency, public transport, sustainable agriculture and conservation of ecosystems, biodiversity and water resources (UNEP, 2011: 14-15). In response, it called for targeted investment amounting to two percent of global GDP in sectors it saw as central to constructing the new green economy. Second, it called for interventions that promote effective ways of valuing the environment to incentivise markets to marshal capital in more sustainable directions.

In many senses these proposals differ little from those of green growth; the main difference comes from the wider goals of the strategy. The chief aim of UNEP's engagement, it argues, is to enable a rapid and effective transition to greener and more poverty-focused development rather than just growth for its own sake. Towards a Green Economy, for example, defines the green economy as "one that results in improved human well-being and social equity, while significantly reducing environmental risks and ecological scarcities” (Endl and Sedlacko, 2012: 5). Death (2014:7) thus distinguishes the UNEP approach as a 'green transformation' in which growth is a means rather than an end and social justice, equity and redistribution and a pro-poor orientation are superimposed on green growth.

The Green Economy and Rio+20: 
Tensions between different interpretations of the green economy were readily apparent during the negotiations surrounding the Rio+20 summit in 2012. Explicitly recognising the limited progress made in embedding sustainable development principles across the globe since the original Rio Summit, UNEP presented the green economy as a radical new organizing principle and rallying cry for rekindling the transformative power of sustainable development. Embracing the green economy, according to UNDESA (2011: v); cited in Brand, 2012), “embodies the promise of a new development paradigm, whose application has the potential to ensure the preservation of the earth's ecosystem along new economic growth pathways while contributing at the same time to poverty reduction.”

Not everyone saw the green economy in this light and heated debate emerged among different geopolitical groupings and interest groups over how the idea should be understood and what role it should play within the negotiations. This was reflected in positions held over wording related to the green economy in the summit's final draft document (see TWN 2012b; 2012c). For those whose views were most influenced by World Bank/OECD perspectives, the green economy was represented as a separate framework for mainstreaming the valuation of "ecosystem services into private sector decision-making” (Hanson et al., 2012). The European Union, Switzerland and South Korea were among those pushing such views, insisting that the green economy should be seen as a standalone issue that all countries should embrace similarly, with implementation largely funded via the private sector. The USA meanwhile argued strongly against tying the green economy to existing sustainable development principles. This, on the other hand, was precisely what other participants wanted in order to render more operational the general principles of sustainability. The G77 group of Southern countries suggested that green economy policies should 
be seen as just one of multiple approaches for achieving sustainable development (TWN, 2012a) and insisted that green economy policies should be guided by existing principles for sustainable development, including the provision of the 'means of implementation' by developed countries.

In the end, the broader interpretations won the day. As one observer commented: “(t)he most significant development...has been the removal of the term 'a green economy' and its replacement by 'green economy policies', indicating the acceptance by developed countries... that the concept as a whole did not have sufficient support, and that states needed to be able to define it to fit their own specific circumstances" (TWN, 2012b). To quote the Venezuelan delegation, the "Green economy has changed from something that is being imposed, to something we own.” (Green Economy Coalition, 2012). Competing interpretations of the green economy nevertheless remain as a major point of fracture in the international community, despite an apparent gradual focusing of agendas towards the wider sustainable development agenda in the months following Rio+20. It will be interesting to see how these debates play out as the framework for the sustainable development goals in the Post-2015 international development settlement is hammered out (Browne and Weiss, 2014).

\section{Situating the Green Economy}

In this section we consider in more detail connections between the underlying positions on the green economy revealed by Rio+20 and debates in the development and geographical literatures on sustainable development. One is firstly struck by the range of positions on where to situate the concept, whose interests it serves, and how it relates to the broader debates about sustainable development (perhaps 
unsurprisingly given its definitional complexity). In essence, advocates of the green economy from different ideological camps have all identified it as providing a unifying banner for re-invigorating the international sustainable development agenda (ICC, 2014). For those closest to 'green growth' perspectives, the focus on economic concerns is presented as inserting a 'much-needed' dose of economic and political realism that focuses on practical action and investment over more ethereal conceptualizations of sustainability. Other advocates are less enamoured of its economic emphases but see the green economy as attempting to bolster fading international commitments to sustainability objectives by articulating a focus on growth and employment that might be more attractive to political and economic elites during a period of financial uncertainty, austerity and geopolitical struggles over the control of resources (Endl and Sedlako, 2012).

For others, especially those espousing the broader UNEP definition, the green economy offers an opportunity to strengthen commitments to all aspects of sustainable development, not just its economic dimensions. Its bringing together of commitments to tackle environmental problems and promise of economic benefits are presented as a win-win combination that offers an opportunity to embed a new global economic orientation that concurrently considers environmental and social issues. In some analyses this has been connected to arguments over the emergence of new political spaces in global policy-making arenas in the aftermath of the global financial crisis that might challenge neoliberal perspectives and articulate more disruptive, radical and interventionist approaches (Cock, 2014; Peters, 2012).

Critics of the green economy remain unconvinced, seeing nothing to suggest a radical break with neoliberal orthodoxies and their limitations (Lander, 2011). For them, the key conduits of green economy thinking have a familiar ring: the 'greening' 
of productivity and innovation, growing marketization (assigning values to previously unpriced resources), the promotion of flexible regulatory frameworks and erosion of state administrative and managerial roles, the privatization of energy, land and water and, generally speaking, and the incorporation of natural capital into economic thinking, all without problematizing the concept of the economy itself (Kenis and Lievens, 2014). The conclusion reached by many development practitioners and academics is that there is little to suggest the green economy envisaged in official and institutional terms represents anything other than an intensification of existing policy directions under neoliberalized environmental governance (Finley-Brook, 2007; Arsel, and Büscher, 2012).

We share many of these concerns. The considerable body of research exploring the impacts of neoliberal environmental governance and conservation strategies (via case studies (Brondo and Bown, 2011; Büscher and Dressler, 2012; Dressler and Roth, 2011; Fletcher and Breitling, 2012; Matulis, 2013; Robertson, 2014) and more generally (Arsel and Büscher, 2012; Brockington and Duffy, 2010; Castree, 2008; Fletcher, 2012; Himley, 2008; McAfee, 2012)), provide a rich source of reflections on the likely implications of green economy initiatives and the accelerated commodification of nature which it seems likely to promote. One key observation from this literature is that commodification processes often have significant distributional implications that tend to reinforce the maldistribution of access to resources and unequal power relations; although this depends on the way initiatives have been planned and implemented, levels of local consultation, preexisting patterns of privilege and exclusion and so on. We return to this discussion below. 
More broadly, the commodification of nature has prompted reflections about broader conceptual and political debates about the historical relationship between capitalism and neoliberalism (for example, whether neoliberalism constitutes a new model of capitalism), capitalism's periodic crises and between capitalism and nature. Some analyses position current nature commodification as the latest of what Gramsci termed capitalism's passive revolutions, "where counter-hegemonic challenges to the dominant capitalist order are co-opted and neutralised through changes and concessions within the dynamics and functioning of the capitalist economy which reestablish the consent in that order" (Wanner, 2014: 6). This has also been related to Polyanian analyses of how capitalism has evolved by mediating "its worst excesses whilst simultaneously trying to open up new avenues for 'moving capital' and securing profit” (Buscher and Arshel, 2012: 130). The key to understanding these transitions in both cases is grasping the evolving alliance of forces brought together to legitimate the new directions (in this case the mix of conservation and development NGOs, international institutions, national governments and industrial/financial interests), which obviously also has utility for those seeking to articulate progressive alternatives to the latest constructions of capitalism. For more detailed exploration of these themes, see Castree (2008) and Wanner (2014).

Returning more directly to the central discourse of green economy proposals and their potential implications for the Global South, the next section considers two specific themes in more detail. One of these is the over-riding technocracy apparent within the various green economy formulations. First, however, we explore some of the silences and limitations within the green economy discourse. 
The phrase 'green economy' is simultaneously attractive in its simplicity and deceptive in concealing tensions between the words 'green' and 'economy'. It suggests an unproblematic elision between deploying the environment to engender new forms of growth, and techno-financial innovation to cleanse problems within the current economy. In this take, “(t)he world's ecosystems are capital assets” (Daily et al., 2000: 395) and the ecosystem is the focus of this semantic transition. The complex mesh of bio-interconnectivity characterizing the world's animal, plant and insect species is reduced to a limited view of their functionality; they are all ecosystem service providers. The semiotics involved are also built on curious uses of language, for instance the Corporate Ecosystem Services Review (Hanson et al., 2012), in which coral reefs constitute erosion control/regulation service providers, and an earthworm is a soil quality maintenance provider.

This focus on ecosystems as service providers to humans is one of the most interesting discursive strategies within green economy interventions. Ironically, whilst the concept of the ecosystem is attracting increased critical attention (O’Neill, 2001), it has been absorbed into green economy thinking for precisely the same reason that its value to ecology and environmental analysis is questioned - its conceptualization as a functional unit:

(T)he ecosystem is not an a posteriori, empirical observation about nature. The ecosystem concept is a paradigm..., a specific way of looking at nature. The paradigm emphasizes... some properties of nature, while ignoring and deemphasizing others.... Ecosystems are now seen as disequilibrial, open, hierarchical, spatially patterned, and scaled (O’Neill, 2001: 3276).

The significance of this for green economy ideation is that, irrespective of conceptual problems, the ecosystem has been pre-selected as the scale at which the green economy should be operationalized, not because this is most relevant to environmental and climatic concerns, but because it represents a convenient scale at 
which "ecosystem production functions" (Daily et al., 2000: 395), and ecosystems services and their interdependencies can be characterized, measured, and monetized (Hanson et al., 2012).

The operationalization of this analysis is one way that market-based rationalizations came to dominate mainstream sustainable development thinking. After the Millennium Ecosystem Assessment (MEA, 2005) established four typologies of ecosystem: provisioning, regulating, cultural and supporting services on which the green economy could be based, UNEP insisted that “(a) green economy does not favour one political perspective over another. It is relevant to all economies, be they state or more market-led" (UNEP, 2011: 7). In effect, this positions marketbased economics as a metanarrative outside politics within which nature itself must be framed, "through pronouncing absolute truths under hegemonic convictions" (Arsel and Büscher, 2012: 65). Such a framing also averts attention from the contribution of socio-economic processes (consumer capitalism and structural inequality) to environmental crises, becoming a discursive device to allay the environmental impacts of consumer societies and reconcile it with new business opportunities for global capital.

As important as capital itself are the corporate conduits through which it is allocated or misallocated, particularly where it concerns corporate concentrations in green economy sectors such as fuels/biofuels, agriculture and food production under a “new constellation” of powerful corporate actors (ETC Group, 2011: iv). The complex and contradictory position of these corporations towards the broader goals of sustainable development is never really acknowledged within the mainstream green economy literature. The UNEP (2012) report, 21 Issues for the 21st Century, for example, frames the background to the 21 issues it identifies in a cursory and 
disembodied fashion. In relation to Issue 003 (Reconnecting Science and Policy), it suggests that "many believe the linkage between the policy and science communities is inadequate or even deteriorating" and that the solution involves "a new look at the way science is organized and how the science-policy interface can be improved” (UNEP, 2012: v), yet nowhere is the role corporate R\&D plays in directing sciencepolicy interfaces addressed. There are, of course, many examples of substantial funding by multinational corporations to promote (for instance) climate change denial $^{6}$ and of close links between the agendas and personal interests of the policy and corporate communities (Helm, 2010). The corporate community has furthermore a powerful ability to co-opt the scientific community to conform to corporate agendas, for instance in recent scandals involving the pharmaceutical industry and regulatory capture (Lofgren, 2013).

Even where UNEP's 21 Issues are intimately connected to the corporatization of globalising capitalism, the transnational corporate actor/community is somehow absent. In the case of the New Rush for Land (Issue 010), the problematic is discussed in terms of investors, host countries and investing countries, whilst the solution is seen as the creation of safeguards directed at those actors and levels. Issue 013 deals with the Potential Collapse of Oceanic Systems, whose problems are described as including "acidification, over-fishing, land and marine-based pollution, widespread habitat destruction” (UNEP, 2012: vii), all directly related to corporate activities in extractive industries, manufacturing and food production. The dispersal of governance across different UN agencies is given as one cause and the solution proffered is a more integrated system, rather than an examination of real-life power structures and control systems. 


\section{Combatting Technocracy}

Deconstructing the green economy from the discourse of powerful institutional actors requires questioning the technological and economistic dimensions of that discourse. The ersatz positivism with which the green economy is couched repeats the win-win emphasis of sustainable development mixed with 'there-is-no-alternative' rhetoric,, and there is little detailed discussion of the trade-offs between different groups of countries, economic sectors, classes and cultures or the power structures that will determine the shape of those trade-offs. As Unmüßig et al. (2012: 36) note: "In all green economy or bio-economy scenarios, political, social, economic and cultural rights are largely left out of the picture.”

Neither are there indications of why a particular suite of green technologies will be more successful at establishing more socially equitable forms of development than previous technologies. One illustration of this is the tendency to view the global energy trilemma (Gunningham, 2013) as a core component of green economy thinking; moves towards low-carbon energy for development encompassing increased energy access (for example, the UN's recognition of the importance of energy for a sustainable future (UN AGECC, 2010)) while also combating climate change. This has seen a proliferation of actors, international institutions, policy measures and capital flows to achieve such goals, most recently visibilized through the UN Sustainable Energy for All (SE4All) initiative and the International Year of Sustainable Energy for All (UN, 2011).

The transfer of low-carbon technologies features highly on the agenda in international climate change negotiations, arguably perpetuating expectations about the power of technology to solve energy and development challenges (Byrne et al., 2012). Financing this transfer and developing innovative financial mechanisms also 
feature strongly in UN calls for new financial vehicles and climate finance to meet the capital requirements needed (estimated at USD \$48-136 billion annually by 2030) to provide access to modern energy services (IEA, 2011).

Byrne et al. (2012) also discuss how the hardware and finance framing of lowcarbon development has resulted in a limited number of policy instruments that neglect important details of how technology can be transferred successfully and sustainably. For instance, their analysis of the Clean Development Mechanism reveals that the majority of registered projects are dominated by just five technology types that are: relatively mature; deployable at a large scale; considered low-risk investments; 'bankable' for the actors involved; and privilege a small number of contexts and technologies.

Achieving and sustaining goals like energy access is more complex than supply-centric technology transfer or provision (Rehman et al., 2012). In this approach, policies tend to consider infrastructure expansion as a guarantee of access, without emphasizing quality, reliability and affordability. Accompanying this, the focus on a universally-accepted definition of energy poverty (Nussbaumer et al., 2011), constructs access as a two-dimensional problem to be fixed with simplistic technological solutions (Makhabane, 2002).

More generally within the green economy, supply-centric approaches to development seem increasingly to be about leveraging finance to roll-out existing and new technologies or a technological approach to developing innovative marketing systems or financial models. Another claimed advantage of this technocratic approach is its ability to run parallel to and interact with corporate ecosystem evaluation (CEV):

The business benefit of using CEV is that it offers a "value-based" lens through which associated environmental, social, economic and financial issues can be quantified, and the trade-offs between them compared (WCSBD, 2011: 4). 
The danger, of course, is that this effectively reduces sustainable development to a series of determinate challenges to be resolved by financial, technical and corporate experts. As the technocratic face of green-economy proposals becomes clearer, many NGOs, although attracted by the overall discourse, are growing increasingly wary. Some are already attempting to forge separate spaces for more participatory debate over the definition and implementation of green economy ideas that might engender less technocentric directions; the Green Economy Coalition housed by the International Institute for Environment and Development is one example. Nevertheless, others are more critical and rather than seeking to engage with and transform green economy thinking, see it as fundamentally about strengthening the prospects for continued growth and capital accumulation and - like mainstream sustainable development - see that it has little potential to address the deeper social and environmental costs and contradictions of capitalist systems. Bearing these critiques of technocratic tendencies within the green economy in mind, we now explore what lessons might be drawn from existing green economy interventions within the Global South.

\section{Green Economy Initiatives in the Global South}

When exploring the potential implications of green economy perspectives for international development, it is important to stress the incredible diversity of the countries encompassed under the banner of the Global South (see Chant and McIlwaine (2009) for debates over the terminology Global North and South). Thus, whilst we raise questions about Northern dominance in some economic sectors encompassed by the green economy, there are certainly areas where countries in the Global South are already substantial players. For instance, in 2011 China, India and 
Brazil demonstrated significant leadership in renewable-energy investment, committing USD \$52, \$12 and \$7 billion respectively and accounting for nearly 30\% of global new investment (Frankfurt School and UNEP, 2012). Amongst the higherincome countries that co-operate within the G77, the most powerful, such as Brazil, are already world leaders in gearing national social welfare programmes towards greening their economies. The export of such credentials is also increasingly evident, as will be discussed shortly.

For the less-powerful, there are always implications with technology transfer; can the deployment of green technologies really help low-income countries to become more integrated, balanced and socially equitable, or will the green economy become another export promotion agency for Northern economies and BRICS? As previously discussed, there are already fears that many legislative and juridical measures being proposed to promote the green economy (environmental standards, subsidies for hightech energy-efficient production techniques and technologies, carbon taxes and environmentally-based conditionality on aid, and carbon tariffs (Endl and Sedlacko, 2012)) may put some Southern countries at a competitive disadvantage, deliberately or not. It is also interesting to note that the removal of agricultural subsidies, often urged on poorer, more agriculturally-dependent countries in the Global South and ignored by powerful food-production regimes of the Global North, is also being reinvented as part of green economy proposals (UNEP, 2012). Clearly, the green economy is not just about technology transfer. It also involves significant interventions spanning markets, social relations, industrial practices and regulatory regimes across countries, all of which carry significant distributional consequences. To give some feel of these complexities and contradictions, we explore the dynamics of two existing examples of green-economy practice: the evolution of the 
Mesoamerican Biological Corridor (MBC) in Central America; and the green economy leadership shown by Brazil.

\section{i) The Mesoamerican Biological Corridor}

The significance of the MBC to the green economy is that it is one of the earliest integrated conservation and development projects (ICDPs) embodying what ideas of sustainable development were supposed to achieve, and was hailed at its inception as the 'longest continuous multinational sustainable development initiative in the world' (World Bank, 2002). It thus serves as a useful illustration of many of the reservations about the green economy (in terms of confusions of understanding and objectives) and of continuities with earlier debates over the meaning of sustainable development (Hill, 2007).

The MBC was established in 1997 as an ambitious project to coordinate ecological protection across Central America whilst also addressing the region's economic and social development and capturing the growing funding available to support sustainability projects in the aftermath of the first Rio Summit (Grandia, 2007). Covering some $30 \%$ of the land area of Central America, the MBC was intended:

[To establish] a territorial planning system consisting of natural protected areas under a special regime whereby core, buffer, multiple use and corridor zones are organized and consolidated in order to provide an array of environmental goods and products to the Central American and the global society, offering spaces for social harmonization to promote investments in the conservation and the sustainable use of natural resources, with the aim of contributing to the improvement of the quality of life of the inhabitants of the region. (Joint Declaration at the 19th Summit of the Central American Heads of State, Panama, 1997, cited in IEGWB, 2011: xv)

Since the MBC was initiated, substantial international, regional and national funds have been invested in initiatives, including by the World Bank through the Global 
Environment Facility, which has provided significant funding for the Nicaragua Atlantic Biological Corridor Project (1997-2005), Honduras Biodiversity in Priority Areas Project (1997-2005), Panama Atlantic Mesoamerican Biological Corridor Project (1998-2005), the Costa Rica Ecomarkets Project (2000-2006), and the Mexico Mesoamerican Biological Corridor Project (2000-2009).

Whilst impetus for the MBC arose immediately after Rio in 1992 and bore evidence of more interventionist impulses, by the time the six-year Establishment of a Program for the Consolidation of the $\mathrm{MBC}$ (PCCBM) programme ${ }^{7}$ was initiated in 2000, market-oriented approaches had consolidated their dominance and the trajectory of the MBC began to follow suit. Over the course of the PCCBM, the MBC shifted from being primarily a mechanism for integrated regional conservation and wholesale transformations in the underlying regional development model to a more "neoliberaldriven logic which placed the emphasis on investment, employment generation and economic growth (as well as property rights and pilot ecosystem service payment initiatives) rather than... strengthening regulation of damaging economic activities, building more effective institutions and more participatory development models or expanding effective biodiversity conservation interventions” (Hill et al., nd). Corson (2010:576) provides a fascinating discussion of how growing collaborations between donors, regional agencies, environmental NGOs and the private sector influenced the evolution of the MBC in these directions.

As a result of contradictory understandings of sustainable development and different agendas among the major actors, operationalizing the ideas behind the MBC became a major problem. Implementation has been hampered by confusing policy aims and little remains by way of sustainable regional organization. In particular, country interests clashed with the regional interests of the project and each country 
had differing ideas on how to deploy the available funding. Belize put the expansion of Mayan cultural tourism at the centre of its project aims; Costa Rica based its planning on strengthening its protected areas system; whereas Mexico subsumed environmental sustainability within its poverty reduction and economic growth agendas. Both Nicaragua and Panama took a more property-rights approach and endeavoured to strengthen legal and regulatory frameworks to protect the environment (IEGWB, 2011).

The most serious threats to regional planning, however, came from existing regional agreements (such as NAFTA) and those being implemented alongside the MBC, such as the Plan Puebla Panama, Mundo Maya and CAFTA. These agreements, representing powerful corporate and regional elite interests whose funding far exceeded that of the MBC, were generally assumed (wrongly) to be complementary to the MBC, rather than challenging it on issues from deforestation to the severance of corridors and buffer zones by transport networks. In the case of NAFTA in Mexico, for instance:

Its progressive elimination of agricultural tariffs engendered a full-blown economic and ecological crisis in the countryside as peasants, unable to compete with agricultural imports from the US, cleared ever-increasing tracts of land while migrating into areas rich in biodiversity in an attempt to survive the crisis. (Ervine, 2010: 778)

Perhaps the most serious failing of the envisioning, planning and deployment of various MBC projects, however, was the effective ‘invisibilization’ of causes of deforestation, such as oil drilling, cattle ranching, logging, export-plantation agriculture, and inequities in land distribution, which both constitute and are coconstituted through processes of structural inequality - these were instead replaced by discourses that stressed insufficient commodification as the chief cause of deforestation (Grandia, 2007). 
The MBC's impacts on sustainable livelihoods have been at best mixed. Irrespective of the participatory intentions of the MBC planners, it remains a topdown, institutionally-led project which was planned, implemented and developed with little participation or buy-in from regional populations afflicted by poverty and on whose behalf the project was allegedly implemented. One indicator of this is the way the majority of funding was co-opted by business-friendly international NGOs (BINGOs), which in several areas has served to create a landed conservation gentry (Ankersen et al., 2006) of European and US citizens with greater access to capital than locals and whose dominance has driven up land prices, further marginalizing the inhabitants (Horton, 2009). Communities in buffer and corridor zones have admittedly received substantial finance and appear to have experienced determinable increases in living standards (IEGWB, 2011), but supported by donor and state funding to the extent that one MBC originator described it as: "welfare nuclei: designated spaces, perhaps with trees, where the needs of humans would be attended to" (Carr, 2004 in Finley-Brook, 2007: 102).

The MBC's record on mitigating deforestation has also been negligible. The evaluation of the IEG (2011) claims to find evidence of decreased deforestation in areas funded by the World Bank, but the overall picture is of increasing deforestation in Central America (Furlong and Netzahualcoyotzi, 2012), particularly in Guatemala, Nicaragua and Honduras. The majority of net gains in the Mexico/Central America region instead occurred in desert/xeric shrub areas in north/central Mexico, outside the MBC; overall, between 1990 and 2008 forests declined from 52\% of Central America's land cover to 46.5\% (Aide et al., 2012). Where reduced deforestation rates have been achieved, DeClerck et al. (2010) claim that it cannot be attributed to effective conservation because "the push factors that continue to spur migration - 
rural poverty, insufficient land, low returns to agricultural activities - remain entrenched” (IEGWB, 2011: xx). The areas protected under the MBC remain severely fragmented, and the regional socio-economy continues to be dominated by the same industrialized export-extractive processes and structures that produced and reproduced social inequality and poverty since the beginning of the 20th Century.

Whilst the MBC is still routinely referred to as an exemplar of sustainable development in international documentation and reports, it has largely disappeared as an integrative regional structure since the end of the PCCBM in 2006. National projects have, however, continued to draw upon the MBC banner to secure international funding or approval, although only really on any significant scale by Mexico. Here, the MBC project has been promoted by the Mexican government and UNEP as exemplifying green economy principles in action (Sarukhan and Icaza, 2012). Whilst this programme appears well integrated into national planning regimes and to adopt a more participatory approach, Ervine (2010) argues that it suffers from similar limitations as the $\mathrm{MBC}$ in relation to top-down project consultation, distributional consequences, and the lack of space for articulating alternatives.

\section{ii) Brazilian Green Economy Leadership}

Policies implemented by the last two Brazilian administrations have combined strong economic performance with apparently strong green credentials. As a result, Brazil is widely regarded as a global leader in areas such as biofuels, a (relatively) clean energy matrix, innovative but controversial policies moving towards the abandonment of landfill, and efforts to protect biodiversity. Nevertheless, these socio-economic successes reflect a strange mixture of poverty-focused interventionism and neoextractivism, with the economy becoming increasingly dependent on traditional 
mineral/agricultural/silvicultural exports, oil and biofuels (Unmüßig et al., 2012). Additionally, Brazil has experienced 'green'-driven deforestation as a result of demand for land for soya and biofuels effectively pushing cattle ranching further into the Amazon (de Sá et al., 2013), despite the development of a new forest code.

Brazil is an emerging economic and political power that, according to Gaetani et al. (2011), is also a global environmental power due to its ecosystem resources and renewable energy potential, strongly positioning the country to incorporate green economy principles provided enabling government policies are place). Beginning in the 1960s with sustainable urban planning initiatives in the city of Curitiba, the development of sustainable development initiatives has led UNEP to label Brazil a green economy success story (UNEP, 2010). Recent developments have also seen Brazil working with UNEP as part of their Green Economy Initiative, and working with the Global Green Growth Institute to establish green growth planning (GEC, 2012).

On energy, Brazil has demonstrated "outstanding host country leadership” in commitments mobilised through Rio+20, under SE4All (UNCSD, 2012: 1). Brazil's domestic commitments amount to hundreds of billions of dollars, with the country pledging to invest in domestic large-scale renewable power (an additional 59,000MW of hydroelectric, wind and biomass capacity by 2022) and the provision of modern energy access to 1.7 million Brazilians by 2014. The state is also implementing actions which will lead to total energy-efficiency savings of 9\% by 2030 (UNCSD, 2012). In addition, Brazil's commitments also reveal aspirations to export its green economy credentials through South-South cooperation, for example, via Brazilian Development Bank commitments to finance feasibility studies for bioenergy 
production in selected Latin American and African countries, and to cooperate with power companies internationally to support sustainable energy.

In the SE4All Action Agenda, Brazil is highlighted as providing "leading examples” of large-scale renewable power and sustainable transportation (UN, 2012b:22-24). However, many commitments under SE4All have raised concerns among civil society actors, who critique SE4All for its technology-neutral approach, wherein no type of energy generation or policy is excluded from support ${ }^{8}$. Concerns also surround the environmental and social costs of Brazil's energy model, in particular the expansion of large scale hydroelectric projects and the substitution of petroleum with ethanol from sugarcane, where state support have been the subject of vociferous internal and external debate.

Additionally, the expansion of Brazil's agricultural frontier combined with a lack of consistent public policies guiding natural-resource exploitation have been cited as contributing to the development of a predatory exploitation model (Irigaray, 2011). Irigaray further argues that this has led to huge economic, social and environmental losses and that Brazilian biomes are significantly threatened despite federal efforts to contain deforestation in the Amazon. In the area of hydropower, around forty large dams are planned in the Brazilian Amazon over the next twenty years (International Rivers, 2012), and several mega-dams are proceeding rapidly, such as Santo Antônio, Jirau, and Belo Monte on the Xingu River (though the latter was recently suspended due to legal battles over its social and environmental impacts (BBC, 2012)).

Brazil's ethanol programme was established in the 1970s and is one of the few biofuels to deliver substantial greenhouse-gas emissions reductions. However, the sector has been criticised for promoting industrial monocropping at the expense of 
natural ecosystems in areas like the Cerrado (Smeets et al., 2008), while concerns have also been raised about the social impacts of sugarcane, particularly exploitative labour conditions (Franco et al., 2010). As the second largest global producer of ethanol, Brazil is increasingly looking to export its biofuel expertise and technologies, leading to arguments that this will encourage other countries to adopt similar models, driving direct and indirect land-use change and unsustainable production processes (Franco et al., 2010).

Competing interpretations thus exist of the implementation of green economy principles in Brazil and the implications of their further development for Brazil's ecological and social sustainability. Irigaray (2011) explores Brazil’s legal environmental framework and argues that while the principles, objectives and directives required for deepening green economy activities are present, serious questions surround their implementation. He also highlights contradictions between the government's ambitious plans to reduce greenhouse-gas emissions whilst also investing in high-impact ventures, such as federal highways, and the high degree of impunity that exists for infractions of existing environmental laws, concluding that such institutional failures must be addressed if Brazil is to remain a poster child for the green economy.

Drawing together the Brazilian and Central American examples, one immediately apparent factor is the overwhelmingly top-down and rarely participatory nature of individual green economy-style projects. Another is their reliance on external financial input and legal restrictions that effectively constitute 'fortress conservation' (see Siurua, 2006 for discussion of this concept). More communityfocused approaches to sustainable livelihoods, particularly in ICDPS, remain highly problematic because "despite many years of experimentation and refinement, clear- 
cut examples of community-based success remain few and far between” (Fletcher, 2012: 296).

Another trait common to both is the assumption that environmental services can be commodified, and commodified in ways that do not clash with existing elite and corporate interests. Instead, in both the MBC and Brazil, powerful elite interests in mining, energy, logging, livestock ranching, export agriculture, tourism, construction and transport remain key actors in developing socio-cultural processes and coercive structures capable of ignoring, obstructing or co-opting green economy initiatives. So-called 'green deserts' ${ }^{9}$ of extractive silviculture, monoculture plantations for paper and palm oil, and large hydro projects are examples of such cooptation.

Furthermore, green economy initiatives throughout Latin America are being implemented as if existing economic legislation, particularly free trade agreements, do not exist or are directly complementary to them. The impact of NAFTA on smallholders in Mexico has been discussed as one example. Poorer Southern countries are at already at a disadvantage in dealing with such treaties given the expense of defending cases; international agreements of this kind privilege the substantial financial power of corporate entities, giving them a major advantage in cases under the aegis of the World Trade Organization.

Finally, there is the question of the ability of green economy initiatives to tackle major ecological challenges, where evidence from the examples is salutary. For example, many socio-economic forces driving deforestation and environmental degradation remain entrenched in both Brazil and Central America: competition for land driving up land prices; the inability of smallholders to compete with subsidized imports causing land abandonment and migration to vulnerable forested land; the 
temptation of illegal logging for quick profits; and socio-cultural environments in which police, political and juridical structures privilege elites over the needs of the poor. The fragile spaces of sustainable livelihoods created by the green economy, in ICDPS and elsewhere, are unable to counter such forces in the short-run or, without massive and continuing support, in the long-run.

\section{Conclusion: Green Economy or 'Old Ghosts'?}

Our core argument in this paper is that the primacy given to economic growth in mainstream ideations of the green economy leaves aside many important questions about social inequality that globalizing capitalism also ignores. How important growth would be in a conceptualization of the green economy that put social equality first is effectively moot, even as it becomes more evident that not just mass consumption in richer countries but also uneven development in the poorer countries are key drivers of global climate change. Furthermore, conceptualizing ecosystems as providers of services which directly or indirectly contribute to human well-being sidesteps the issue of inequality and begs the questions, what kind of well-being and well-being for whom?

Despite this, the green economy is being proposed, at least partly, as a mechanism for bridging inequality gaps within a set of unstated presuppositions based on the neoliberal orthodoxy that introducing a market economy to the environment can act to address social inequality. Simultaneously, it is assumed that 'green markets' can accurately price the planetary assets on which human life depends in ways that balance consumption with survival - in other words, that prices arrived at by valuing ecosystems services really are directly equivalent to the value of human life. No empirical data is offered to support this, because no such evidence exists. As Fletcher 
(2012: 298) suggests, it is time to consider "that market-based capitalist mechanisms may be simply incapable of providing for either income generation or environmental protection on a global scale given present levels of inequality throughout the world.”

How then should we respond to the green economy? By opposing it? By engaging with it and working to promote different interpretations of what a green economy might constitute? Or by seeking to challenge its dominance by rallying an alliance of forces around alternative less econocentric concepts? The green economy's four fundamental goals of promoting "improved human well-being and social equity, while significantly reducing environmental risks and ecological scarcities” (UNEP 2010: 5) are not unrealizable. The problem is that the mechanisms selected by its most powerful proponents, such as "green investment, creation of green jobs, market creation... support of international trade, and circular economy” (Endl and Sedlacko, 2012: 5) were not chosen because they were the most effective way of achieving these goals, but because those institutions were discursively programmed to couch the green economy in these terms. Even if evaluating ecosystems and the value of changes in ecosystems services (DEFRA, 2007: 12) prove to be an appropriate course, it is a perilous task because:

The fundamental problem is that Homo sapiens is moving ecological systems outside the envelope of conditions that have existed over evolutionary history. This is terra incognita and the assumption that ecological systems will respond stably is unjustified (O’Neill, 2001: 3282).

This is the crux of the problems underlying the visions of the green economy laid out by UNEP, the OECD and other transnational institutional actors. Within the scientific debate over climate change, to the extent that social inequality, mass consumption and the flawed governance of globalization have been central causes of global environmental change, they remain part of the strategy for change. Equally, 
within the moral economy of development, flawed assumptions about the inevitability of market-based solutions, the relative unimportance of increasing social inequality and a community of interest between the richest and the world's poorest continue to inform thinking on the green economy. To the critical eye, green economy thinking to date appears to encapsulate the worst of both theoretical worlds.

\footnotetext{
${ }^{1}$ Our friend and colleague Paul Johnson tragically died in April 2012 when we were doing the initial groundwork on this paper. He was a much valued colleague and made a major contribution to the UK Low Carbon Energy for Development Network which we draw upon in the paper. We dedicate this paper to his memory. For more information visit: http://phjcirhep.yolasite.com/

${ }^{2}$ Chloe Hill developed the analysis around the Mesoamerican Biological Corridor. That section of the paper draws heavily on her doctoral work and subsequent consultancy on the project.
}

${ }^{3}$ Rio+20 is the abbreviation for the United Nations Conference on Sustainable Development which took place in Rio de Janeiro in June 2012, 20 years after the 1992 Earth Summit.

${ }^{4}$ These are the two most significant influences on the concept of the green economy within international development debates. Other treatments also mention New York Times columnist Thomas Friedmann's calls for a 'green new deal' of major global investment to promote a green version of Roosevelt's economic new deal of the 1930s.

${ }^{5}$ The GGKP was established in January 2012 by the Global Green Growth Institute, the Organisation for Economic Co-operation and Development, the United Nations Environment Programme and the World Bank.

${ }^{6}$ Perhaps the best-known example was the Royal Society letter to Exxonmobil accusing it of presenting an inaccurate and misleading view of climate science and providing funding to groups contributing to these views

(http://royalsociety.org/uploadedFiles/Royal_Society_Content/policy/publications/20 06/8257.pdf.

${ }^{7}$ The PCCBM was a $\$ 20$ million six-year programme of regional coordination for the MBC under the direction of the Comisión Centroamericana de Ambiente y Desarollo.

${ }^{8}$ A statement signed by 107 civil society organisations argued that the initiative was 'inadequate, non-inclusive and will not achieve the level of change required to tackle both energy poverty and dangerous climate change' (http://www.unngls.org/IMG/pdf/FOE_SE4All_CSO_Statement_with_signatures.pdf. 
${ }^{9}$ See "'Green desert' monoculture forests spreading in Africa and South America”, Guardian 26/9/11, http://www.guardian.co.uk/environment/2011/sep/26/monocultureforests-africa-south-america. 


\section{References}

ADAMS, W. (2009): Green Development: Environment and Sustainability in a Developing World. $3^{\text {rd }}$ Edition, London, Routledge.

AIDE, T., ClARK, M., GRAU, H., LÓPEZ-CARR, D., LEVY, M., REDO, D. BONILLA-MOHENO, M., RINER, G., ANDRADE-NÚÑEZ, M. and MUÑIZ, M. (2012): 'Deforestation and reforestation of Latin America and the Caribbean 20012010’, Biotropica 45 (2): 262-271.

ANKERSEN T., REGAN. K. and MACK, S. (2006): 'Towards a bioregional approach to tropical forest conservation: Costa Rica’s Greater Osa bioregion’, Futures 38 (4): 406-431.

ARSEL, M. and BÜSCHER, B. (2012): 'Nature ${ }^{\mathrm{TM}}$ Inc.: changes and continuities in neoliberal conservation and market-based environmental policy', Development and Change 43 (1): 53-78.

BÄR, H., JACOB, K. and WERLAND, S. (2011): Green economy discourses in the run-up to Rio 2012, FFU-Report 07-2011 Freie Universität Berlin, Environmental Policy Research Centre.

BBC (2012): Work to resume on Brazil's Belo Monte dam [online]. http://www.bbc.co.uk/news/world-latin-america-19404740 [accessed 10 June 2014].

BRAND U. (2012): ‘Green economy - the next oxymoron? No lessons learned from failures of implementing sustainable development', GAIA 21 (1): 28-32.

BROCKINGTON, D. and DUFFY, R. (2010): 'Capitalism and conservation: the production and reproduction of biodiversity conservation', Antipode 42 (3): 469-484. BRONDO, K. and BOWN, N. (2011): 'Neoliberal conservation, Garifuna territorial rights and resource management in the Cayos Cochinos marine protected area', 
Conservation and Society, 9 (2): 91-105.

BROWNE, S. and WEISS, T. (2014): 'The future UN development agenda:

contrasting visions, contrasting operations', Third World Quarterly DOI:

$10.1080 / 01436597.2014 .915160$

BRUNDTLAND, G. (1987): Our Common Future: Report of the 1987 World Commission on Environment and Development. Oxford University Press, Oxford.

BÜSCHER, B and DRESSLER, (W) (2012): 'Commodity conservation: the restructuring of community conservation in South Africa and the Philippines', Geoforum 43 (3): 367-376.

BYRNE, R., SMITH, A., WATSON, J. and OCKWELL, D. (2012): 'Energy pathways in low carbon development: the need to go beyond technology transfer', in OCKWELL, D. and MALLETT, A. (eds): Low Carbon Technology Transfer: from Rhetoric to Reality. Routledge, Abingdon, pp. 123-142.

CASTREE, N. (2008): 'Neoliberalising nature: the logics of deregulation and regulation’, Environment and Planning A 40 (1): 131-152.

CHANT, S and MCILWAINE, C. (2009): Geographies of Development in the 21st Century: An Introduction to the Global South. Edward Elgar, Cheltenham.

COCK, J. (2014): ‘The 'green economy': a just and sustainable development path or a 'wolf in sheep's clothing'?', Global Labour Journal 5 (1): 23-44.

CORSON, R. (2010): 'Shifting environmental governance in a neoliberal world: US AID for conservation', Antipode 42 (3): 576-602.

CRIST, E. (2007): 'Beyond the climate crisis: a critique of climate change discourse', Telos 4 (winter): 29-55.

DAILY, G., SÖDERQVIST, T., ANIYAR, S., ARROW, K., DASGUPTA, P., EHRLICH, P., FOLKE, C., JANSSON, A., JANSSON, B., KAUTSKY, N., LEVIN, 
S., LUBCHENCO, J., MÄLER, K., SIMPSON, D., STARRETT, D., TILMAN, D. and WALKER, B. (2000): 'The value of nature and the nature of value', Science 289 (5478): 395-396.

DEATH, C. (2014): 'The green economy in South Africa: global discourses and local politics’, Politikon: South African Journal of Political Studies 41 (1): 1-22.

DECLERCK, F., CHAZDON, R., HOLL, K., MILDER, J., FINEGAN, B., MARTINEZ-SALINAS, A., IMBACH, P., CANET, L. and RAMOS, Z. (2010): 'Biodiversity conservation in human-modified landscapes of Mesoamerica: past, present and future', Biological Conservation 143 (10): 2301-2313.

DE SÁ, S., PALMER, C. and DI FALCO, S. (2013) 'Dynamics of indirect land-use change: empirical evidence from Brazil', Journal of Environmental Economics and Management 65 (3): 377-393.

DRESSLER, W. and ROTH, R. (2011): 'The good, the bad and the contradictory: Neoliberal conservation governance in Rural Southeast Asia', World Development 39 (5): $851-862$.

ENDL, A. and SEDLACKO, M. (2012): National Sustainable Development Strategies: What Future Role with Respect to Green Economy? European Sustainable Development Network, Vienna.

ERVINE, K. (2010): 'Participation denied: the Global Environment Facility, its universal blueprint, and the Mexico-Mesoamerican Biological Corridor in Chiapas', Third World Quarterly 31(5): 773-790.

ETC GROUP (2011): Who Will Control the Green Economy? ETC Group Communiqué no. 107, November 2011.

FRANCO, J., LEVIDOW, L., FIG, D., GOLDFARB, L., HÖNICKE, M. and MENDONÇA, M. (2010): 'Assumptions in the European Union biofuels policy: 
frictions with experiences in Germany, Brazil and Mozambique', Journal of Peasant Studies 37(4): 661-698.

FINLEY-BROOK, M. (2007): ‘Green neoliberal space: the Mesoamerican biological corridor', Journal of Latin American Geography 6(1): 101-124.

FLETCHER, R. (2012): 'Using the master’s tools? Neoliberal conservation and the evasion of inequality', Development and Change 43 (1): 295-317.

FLETCHER, R. and BREITLING (2012): 'Market mechanism or subsidy in disguise? Governing payment for environmental services in Costa Rica’, Geoforum 43 (3): $402-$ 411.

FURLONG, A. and NETZAHUALCOYOTZI, R. (2011): 'Poverty and social exclusion in the context of the Puebla- Panama Plan', Suma de Negocios 3 (1): 7-19. FRANKFURT SCHOOL and UNEP (2012) Global trends in renewable energy $2012 \quad$ [online]. $\quad$ http://fs-unepcentre.org/sites/default/files/publications/globaltrendsreport2012final.pdf [accessed 9 January 2013].

GAETANI, F., KUHN, F. and ROSENBERG, R. (2011): 'Brazil and the green economy: a panorama’, Política Ambiental, 8: 76-86.

GRANDIA, L. (2007): 'Between Bolivar and bureaucracy: the Mesoamerican Biological Corridor', Conservation and Society 5 (4): 478-503.

GEC (GREEN ECONOMY COALITION) (2012): Surveying the green economy and $\begin{array}{lll}\text { green growth landscapes } & \text { [online]. }\end{array}$ http://www.greeneconomycoalition.org/sites/greeneconomycoalition.org/files/GEC\% 20background\%20paper final\%20.pdf [accessed 9 June 2014].

GUNNINGHAM, N. (2013): 'Managing the energy trilemma: the case of Indonesia', Energy Policy, 54: 184-193. 
HANSON, C., RANGANATHAN, J., ICELAND, C. and FINISDORE, J. (2012): The Corporate Ecosystem Services Review: Guidelines for Identifying Business Risks and Opportunities Arising from Ecosystem Change: Version 2.0. World Resources Institute, Washington, DC.

HELM, D. (2010): 'Government failure, rent-seeking, and capture: the design of climate change policy', Oxford Review of Economic Policy 26 (2): 182-196.

HILL, C. (2007) The ambiguities of sustainable development and conflicts within environmental governance in Central America: the case of the Mesoamerican biological corridor [online]. https://dspace.lboro.ac.uk/dspace-jspui/handle/2134/7886 [accessed 9 June 2014].

HILL, C., BROWN, E. and BULLARD, J. (ND) 'Learning From Past Failures? Conflicting Approaches towards Sustainable Development and the Evolution of the Mesoamerican Biological Corridor,' paper submitted to Geographical Journal.

HIMLEY, M. (2008): 'Geographies of environmental governance: the nexus of nature and neoliberalism', Geography Compass 2 (2): 433-451.

HORTON, L. (2009): 'Buying up nature: economic and social impacts of Costa Rica’s ecotourism boom’, Latin American Perspectives 36 (3): 93-107.

ICC (INTERNATIONAL CHAMBER OF COMMERCE) (2014): ICC Green Economy Policy [online]. http://www.iccwbo.org/advocacy-codes-and-rules/areas-ofwork/environment-and-energy/icc-green-economy-policy/l [accessed 11 June 2014]. IEA (INTERNATIONAL ENERGY AGENCY) (2011): Energy for all: financing access for the poor - special early excerpt of the World Energy Outlook 2011. OECD/IEA, Paris. 
IEGWB (INDEPENDENT EVALUATION GROUP OF THE WORLD BANK)

(2011): The Mesoamerican Biological Corridor, Regional Program 5. World Bank, Washington DC.

INTERNATIONAL RIVERS (2012): The Amazon: dirty dams, dirty politics and the myth of clean energy [online]. http://www.internationalrivers.org/resources/theamazon-dirty-dams-dirty-politics-and-the-myth-of-clean-energy-7495 [accessed 13 June 2014].

IRIGARAY, C.T.J.H. (2011): 'The transition to a green economy in Brazilian law: perspectives and challenges’, Política Ambiental, 8: 151-165.

JACOBS, M. (1991): The Green Economy: Environment, Sustainable Development and the Politics of the Future. Pluto Press: London.

JELLINEK, S., SERRANO, S., and EBRO, K. (2002): International community commits long term support to Mesoamerican Biological Corridor (MBC) [online]. http://go.worldbank.org/NKNAZDQCT0 [accessed 11 June 2014].

KENIS, A. and LIEVENS, M. (2014): Greening the economy or economizing the green project? When environmental concerns are turned into a means to save the market', paper forthcoming in Review of Radical Political Economics.

LANDER, E. (2011): The green economy: the wolf in sheep's clothing [online]. http://www.tni.org/report/green-economy-wolf-sheeps-clothing [accessed 9 June 2014].

LOFGREN, H. (2013): 'The politics of the pharmaceutical industry and access to medicines', in LOFGREN, H. (ed) The Politics of the Pharmaceutical Industry and Access to Medicines: World Pharmacy and India. Social Science Press, New Delhi, India, pp.1-23 
MAKHABANE, T. (2002): 'Promoting the role of women in sustainable energy development in Africa: networking and capacity-building', Gender and Development 10 (2): 84-91.

MATULIS, B. (2013): 'The narrowing gap between vision and execution: neoliberalization of PES in Costa Rica', Geoforum 44: 253-260.

MCAFEE, K. (2012): ‘The contradictory logic of global ecosystem services markets’, Development and Change 43 (1): 105-131.

MEA (2005): Ecosystems and Human Wellbeing: Biodiversity Synthesis. Island Press, Washington DC.

NUSSBAUMER, P., BAZILIAN, M., MODI, V. and YUMKELLA, K. (2011): 'Measuring energy poverty: focusing on what matters', Oxford Poverty and Human Development Initiative Working paper 42.

O’NEILL, R. (2001): 'Is it time to bury the ecosystem concept? (with full military honors, of course!)', Ecology 82 (12): 3275-3284.

OECD (2011): Towards Green Growth. OECD, Paris.

OECD (2012): OECD Environmental Outlook to 2050. OECD, Paris.

PEARCE, D., MARKANDYA, A. and BARBIER, E. (1989): Blueprint for a Green Economy. Earthscan, London.

PETERS, M. (2012): Greening the knowledge economy: a critique of neoliberalism [online]. $\quad$ http://truth-out.org/news/item/9642-greening-the-knowledge-economy-acritique-of-neoliberalism [accessed 13 June 2014].

RACO, M. (2005): 'Sustainable development, rolled-out neoliberalism and sustainable communities', Antipode 37 (2): 324-347.

REHMAN, I.H., KAR, A., BANERJEE, M., KUMAR, P., SHARDUL, M., MOHANTY, J. and HOSSAIN, I. (2012): 'Understanding the political economy and 
key drivers of energy access in addressing national energy access priorities and policies’, Energy Policy, 47 (1): 27-37.

ROBERTSON, M. (2004): 'The Neoliberalization of ecosystem services: Wetland mitigation, banking and problems in environmental governance', Geoforum, 35 (3): $361-373$.

SARUKHAN, J. and ICAZA, P. (2012): 'Building green bridges: the Mesoamerican Biological Corridor and the Mexican experience', The Road to Río+20, United Nations Conference on Trade and Development (UNCTAD) 3: 64-69.

SIURUA, H. (2006): 'Nature above people: Rolston and "fortress" conservation in the South', Ethics and the Environment 11 (1): 71-96.

SMEETS, E., JUNGINGER, M., FAAIJ, A., WALTER, A., DOLZAN, P. and TURKENBURG, W. (2008): 'The sustainability of Brazilian ethanol - an assessment of the possibilities of certified production', Biomass and Bioenergy, 32 (8): 781-813. Third World Network (TWN) (2012a) No agreement and deep division on 'green economy' [online]. www.twnside.org.sg/title2/rio+20/news_updates/TWN_update6.pdf [accessed 8 February 2013].

TWN (2012b): Differences remain despite some common understanding on 'green economy' approach [online]. www.twnside.org.sg/title2/rio+20/news_updates/TWN_update11.pdf [accessed 8 February 2013].

TWN (2012c): Overview of outcome and negotiations of 'green economy' [online]. http://twnside.org.sg/title2/rio+20/news_updates/TWN_update17.pdf [accessed 8 February 2013]. 
UN AGECC (UNITED NATIONS ADVISORY GROUP ON ENERGY AND

CLIMATE CHANGE) (2010): Energy for a Sustainable Future. United Nations, New York.

UN (UNITED NATIONS) (2011): Sustainable Energy for all: a Vision Statement by Ban Ki-Moon Secretary General of the United Nations. United Nations, New York.

UN (2012a): Resilient People, Resilient Planet: A Future Worth Choosing. United Nations, New York.

UN (2012b): Sustainable Energy for All: A Global Action Agenda. United Nations, New York.

UNCSD (UNITED NATIONS CONFERENCE ON SUSTAINABLE

DEVELOPMENT) (2012): Sustainable Energy for All Commitments Highlights at Rio+20 [online].

https://www.uncsd2012.org/content/documents/759SG\%20Sustainable\%20Energy\%2 Ofor\%20All\%20-\%20commitments\%20press\%20release.pdf [accessed 7 November 2012].

UNEP (UNITED NATIONS ENVIRONMENT PROGRAMME) (2010): Green Economy: Developing Countries Success Stories. United Nations, New York.

UNEP (2011): Towards a Green Economy: Pathways to Sustainable Development and Poverty Eradication: A Synthesis for Policy Makers. UNEP, Nairobi.

UNEP (2012): 21 Issues for the 21st Century: Results of the UNEP 2011 Foresight Process on Emerging Environmental Issues. UNEP, Nairobi.

UNMÜßIG, B., SACHS, W. and FATHEUER, T. (2012): Critique of the Green Economy: Toward Social and Environmental Equity. Heinrich Böll Foundation, Berlin. 
WANNER, T. (2014): 'The new 'passive revolution' of the green economy and growth discourse: maintaining the 'sustainable development' of neoliberal capitalism’, New Political Economy DOI: 10.1080/13563467.2013.866081.

WHILE, A., JONAS, A. E. G. and GIBBS, D. (2010): ‘From sustainable development to carbon control: eco-state restructuring and the politics of urban and regional development', Transactions of the Institute of British Geographers 35 (1): 76-93.

WONG, S. (2012): ‘EU’s ‘renewable revolution’: does it create more energy injustice in developing countries?’ Journal of Earth Sciences and Climatic Change 3(1): 1.

WORLD BANK (2002): Biodiversity and Forests at a Glance. World Bank, Washington DC.

WORLD BANK (2003): World Development Report 2003: Sustainable Development in a Dynamic World: Transforming Institutions, Growth, and Quality of Life. World Bank, Washington DC.

WORLD BANK (2012) Inclusive Green Growth: The Pathway to Sustainable Development. World Bank, Washington DC. 